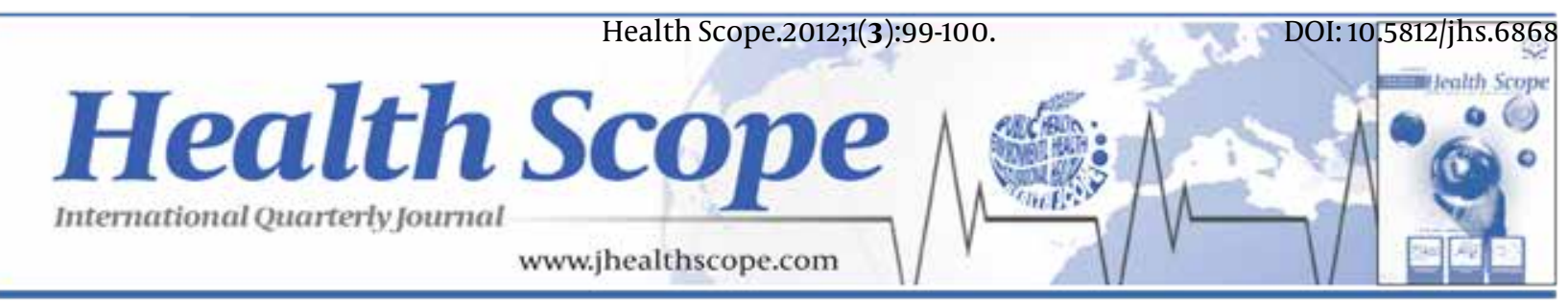

\title{
More About Radioactive Pollution
}

\author{
Farnaz Tabatabaei ${ }^{1,2^{*}}$ \\ ${ }^{1}$ Department of Medical Radiation Engineering, Science and Research Islamic Azad University, Tehran, IR Iran \\ ${ }^{2}$ Kowsar Corporation, Tehran, IR Iran
}

A R T I C L E I N F O

Article type:

Editorial

Article history:

Received: 19 Jun 2012

Revised: 26 Jun 2012

Accepted: 10 Jul 2012

Keywords:

Radioactive

Air Pollution

Radiation is the emission of particle or energy in wave form. This is stated as electromagnetic radiation. Examples consist of: visible light, radio waves, microwaves, infrared and ultraviolet lights, X-rays, and gamma-rays (1). Radiation can be described as two basic types, ionizing and non-ionizing radiation. The discussion will include a review of radiation of radioactivity. There are three main kinds of ionizing radiation which are included alpha particles, beta particles and gamma rays. Beside these there forms of ionizing also we have neutrons, protons, heavy charged particles, X-ray and others. Radioactive substance can penetrate into the body by inhalation, ingestion or dermal absorption. In addition, gamma radiation external to the body can enter the skin and produce a dose various tissues (2). Non ionizing radiation refers to radioactive energy which as opposed to produce charged ions when passing through matters has enough energy only for excitation. However it is known to cause biological effects. Non ionizing radiations usually work together with tissue through the generation of heat. The hazard
-Implication for health policy/practice/research/medical education:

This manuscript focused on different kind of radiations and effects of those in human body and environment. It could be effective for who is interested in knowledge of radiation.

- Please cite this paper as:

Tabatabaie F. More About Radioactive Pollution. Health Scope. 2012; 1(3): 99-100.

depends on the ability to go through the human body and the absorption characteristics of different tissues (3).

If each and every one of these types of radiation added by human activities can cause radiation pollution. The meaning of radiation pollution is that while there are omnipresent sources of radiation, generally the highenergy radiations cause radiation pollution with a serious health risk (such as cancer or death) (4). As has been mentioned air pollution can caused by radioactivity which are in the air as gas or aerosols that emit such ionizing radiation as alpha and beta particles, gamma rays, neutrons and other high energy quanta. From the beginning of the life story the man has been exposed to ionizing radiations from radioactive isotopes and other sources by development of atomic reactor. This kind of pollution has been raised considerably (5, 6). Exposure radiation can cause tissue and organ injury unless suitable precautions are taken. The more important health effects described as being caused by radioactive isotopes are blood abnormalities, skin changes, bone

\footnotetext{
*Corresponding author: Farnaz Tabatabaei, Kowsar Corporation, Tehran, IR Iran. Tel/Fax: +98-2188621755. E-mail: tabatabaei@mykowsar.com
} 
changes and soforth.

Physical half-life of radioactive isotopes causes the amount of injury in human body. The most in danger part of body is where have many actively dividing cells such as the skins, intestine, gonads and tissues that grow blood cells (7). The Radiation has most damaging effect on single celled organisms because a single cell damaged by radiation can in a roundabout way affect other cells in the individual. Cells which exposed with low energy radioactivity can have biochemical repair system which can repeal some damage. Actually it is good to mention that all humans during their life are exposed to radiation in really small doses (8). Radioactive pollution is a vital ecological crisis. It could be much worse if extreme caution is not utilized in the handling and use of radioactive material, and in the design and operation of nuclear power plants (9).

There are three basic tools that can provide protection against a radiation source. These are time, distance and shielding. The goal of the protection is to prevent over exposure from external radiation and to minimize the entry of radionuclides into the body or minimize internal radiation. Controlling Radiation Pollution can be done at various levels, such as usage and treatment of radiation waste, the control and mitigation of nuclear accidents, as well as the control and minimization of personal exposure to radiation at an individual level .Apart from being an inevitable series of negative effects of radiations, it is the duty of humans with regard to Radiation Standards Organizations to help in reducing the harmful effects of this kind of pollution.

\section{Acknowledgments}

The author would like to thanks Dr. Mirzaie for his guidance in preparing this article.

\section{Authors' Contribution}

This article has been done completely by author.

\section{Financial Disclosure}

None declared.

\section{Funding/Support}

None declared.

\section{References}

1. Kovac D, Ruisel I, Benuskova Z. [Is a unilateral preference in the systems eye-hand and foot-hand (author's transl)]. Bratisl Lek Listy. 1975;64(2):177-83.

2. Kwan-Hoong N. Non-Ionizing Radiations - Sources, Biological Effects, Emissions and Exposures Kuala Lumpur 2003; Available from: http://www.who.int/peh-emf/meetings/archive/en/keynote3ng.pdf.

3. Mathew S, Rajagopalan M, Abraham JP, Balakrishnan D, Umadevi AG. Natural Radioactivity Content in Soil and Indoor Air of Chellanam. Radiat Prot Dosimetry. 2012.

4. Radiation Pollution. 2009; Available from: http://www.environmentalpollutioncenters.org/radiation/.

5. Nel A. Air pollution-related illness: effects of particles. Science 2005;308(5723):804-6.

6. Vesilind PA, Peirce JJ. Environmental pollution and control.1983.

7. Gadd G. Influence of microorganisms on the environmental fate of radionuclides. Endeavour. 1996;20(4):150-6.

8. Upton AC. Biological effects of low-level ionizing radiation. Sci Am;(United States).1982;246(2).

9. Eisenbud M, Gesell TF. Environmental radioactivity: from natural, industrial, and military sources. Academic Pr; 1997. 